Anat. Labor. of Prof. H. SETO, Tohoku University, Sendai.

\title{
On Innervation, Especially, Sensory Innervation of Rectum and Anus in Canine Fetus.
}

\author{
犬胎児の直腸及び肚門の神経特に知覚神経分布に就て。

\section{Shisei KAKAZU 嘉 数 至 政.} \\ (Received July 18, 1957.)
}

In 1940, SETO made a study on the sensory innervation of the anus of human adults and fetus and ascertained the existence of numerous intraepithelial fibres in the anal zonae columnaris and intermedia. In 1955, IZUMI published a supplementary study thereto, in which he described, beside intraepithelial fibres, many subepithelial sensory terminations too in detail. In the next year, SETO discovered that a small number of my. elinated thick sensory fibres come into the distal part of the rectum of human adults, to end in simple branched terminations around the crypts there. These studies have contributed to throw much light on the sensory innervation of the lowest part of the human alimentary canal. In this laboratory, a series of studies on the anus of various animals have been conducted, SHIMODA, NIIZUMA and YOKOYAMA publishing works on dog, bat and cat anus respectively, and many interesting informations have been given out.

The present author also had an opportunity of conducting a similar research with the caudal part of the alimentary canal of $\operatorname{dog}$ in the latter fetal stage as subject from the embryologic point of view. The materials, consisting of the rectum and the anus, were fixed in $10 \%$ neutral formol solution for a long time, cut into $40 \mu$ sagittal frozen sections, stained by SETO's impregnation. in general use at this laboratory and the large series of histologeal preparations thus obtained were subjected to minute microscopic examination. Studying the observatins in comparison with the findings obtained in the study of the same parts of human fetus (SETO), the results reported in the following were arrived at.

\section{Individual Observations.}

The distal part of the rectum and the anus of dog are already in nearly full formation in the later fetal stage, and in particular, the very dense arrangement of goblet cells in the crypts in the rectum, as dense as in adult dogs, is conspicuous. The anus is also so far developed as to be clearly 
divisble into the zonae columnaris and intermedia belonging to the mucous part and the zona cutanea. In the first place, I wish to outline my findings on the histology of these parts, but since in this paper, I will limit myself to the mucous part, relegating the zona cutanea to a future occasion, I will describe the histological development of the mucous part of the anus of fetal dog alone hereunder.

The anal mucous part of canine fetus in the latter stage is far shorter than that in human fetus, both the zonae intermedia as well as the columnaris being very narrow in formation, as shown in Fig. 1. The epithelium

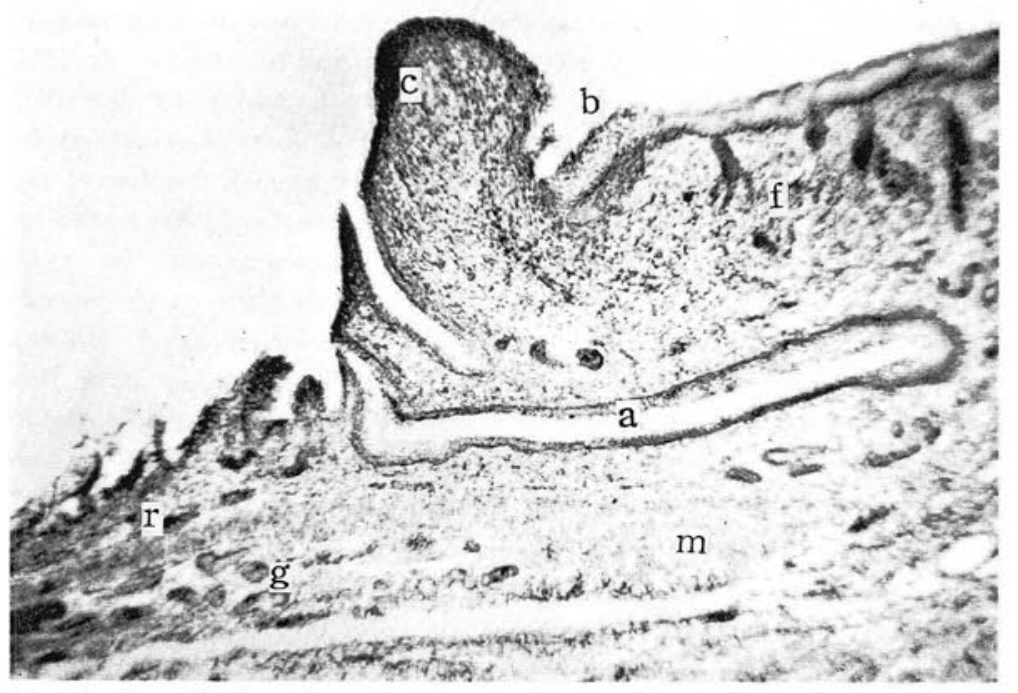

Fig. 1. A sagittal section of rectum and anus of a canine embryo in latter stage. $r$ mucous membrane of rectum, $c$ zona columnaris, $b$ bladder-like stratified epithelium of zona intermedia, $f$ hair follicles in zona cutanea, $a$ anal canal, $g$ proctal glands, $m \mathrm{~m}$. sphincter ani int. Details in the text. SETO's impregnation. Photo $\times 40$.

of the zona intermedia is a bladder-like stratified epithelium, quite similar to that in man, but in thickness it is smaller in dog fetus. In human fetus, a papillar formation from the lamina propria into the epithelium in this part is already barely perceptible, but in canine fetus such a formation is not to be observed. As the papillar formation in this part is scarcely developed even in adult dogs (SHIMODA), it is natural that such a formation is absent in dog fetus.

The lamina propria in this part, as in the zona columnaris treated below, is composed of a connective tissue extremely rich in connective 
tissue cells containing spindle-form cell nuclei. As in the canine fetus, there are no longitutional muscle fibres extending from the muscularis mucosae of the rectum to separate this layer from the submucosa, as in human fetus, the boundary between the propria and the submucosa is not so distinct as in man. This indistinctness of boundary between the two layers is also notable in the zona columnaris. Blood vessels, especially, young veins, are very perceptibly developed in this subepithelial layer of connective tissue.

The zona columnaris consists of columnae and sinus and the epithelium lining the former of 3-4 rowed cylindrical cells. In some places, however, flat epithelium is already in formation. In the sinus, the epithelium is a stratified cylindrical one taller than the above. In the human anus, no papillae are formed out of the propria into the epithelium, but in adult dog the papillar formation is considerably marked (SHIMODA). In my $\operatorname{dog}$ fetus, papillae were found already in uneven formation, particularly notable in the part nearer the rectum.

In dog fetus, anal canals, beginning in the epithelium of the zona columnaris, running down through the subepithelial connective tissue longitudinally and terminating in blind ends, are in good formation, but in number, these are smaller than in human fetus. These canals are also lined with tall stratified cylindrical epithelium.

The proctal glands are merely rudimentary formations in man and little better developed in cat, but in adult dogs, they are very well developed, being powerfully formed not only in the mucous membrane, but also in the muscularis and often even in the adventitia. Not at all rarely these glands are found extending into the rectal mucous membrane. The formation of these glands is very powerful in dog fetus of the latter stage and are located in nearly the same manner as in adult dogs, but in development they are yet somewhat far from completion, the end parts of the glands being still in the form of mere cords composed of 1-2-rowed young epithelial cells lacking in the full traits of mucous glands as yet. Their ducts are also canals lined with 2-3-rowed cylindrical epithelium and not yet fully developed into the specific formation seen in adult dogs. These ducts usually open out into the sinus, but some of them open out into the columnae of the zona columnaris.

The muscularis of the rectum is formed of an inner circular and an outer longitudinal layers, extends down to the zona intermedia of the anus and its circular layer finally passes over into the $\mathrm{m}$. sphincter ani internus. SHIMODA has discovered another circular layer similarly formed of smooth muscle fibres running along the outside of the outer layer in the caudal part of the rectnm of adult dog. In my fetal specimens, this third muscle layer of smooth muscle fibres located at the highest end of the sphincter 
ani externus was not at all well developed and hardly worth of special mention. On the other hand, to my great interest, I found a part of the outer longitudinal muscle layer of the rectum running down along the outside of the sphincter ani externus, gaining in strength and finally ending on the inside of the os coxae. I wish to name this muscle the m. dilatator ani.

The ganglia in AUERBACH's plexus are generally found between the outer longitudinal and the inner circular muscle layers, but often enough within these muscle layers and in a small number in my so-called $\mathrm{m}$. dilatator ani too. Such ganglia are found already in formation in the MEISSNER's plexus also. These ganglia are found not only in the rectum, but also in the anus, where, however, they are less well developed.

The ganglion cells are as yet very poor in development, their multipolarity being scarcely demonstrable. They are found buried amidst numerous fine fibres as merely apolar round cells in most cases, those in the MEISSNER's plexus being particularly ill developed.

The incoming nerve fibres supplied to the distal part of the rectum first run into the AUERBACH's plexus and thence into the MEISSNER's plexus in the submucosa, to come into close relation with these. These nerve fibres mainly consist in very fine vegetative fibres, but a small number of thick sensory fibres are found commingled. The vegetative fibres, as may be expected from the results of many a past study at this laboratory, end in STÖHR's terminal recticula (Fig. 9) standing in control by contact over many kinds of the governed cells. These reticula are already fully developed to perfection in canine fetus.

That sensory fibres are found running into the caudal part of the rectum as well and form their terminations in the mucous membrane has been ascertained beyond doubt by many recent research works at this laboratory. For example, SETO has demonstrated noticeable formation of sensory terminations in the rectum of human adults, SHIMODA in that of adult dog, NIIZUMA in that of bat and YOKOYAMA in that of cat. These discoveries were all made in the rectum of adult animals, but no ontological treatment of the problem using embryonic or fetal animals has ever been reported. Now in my specimens of canine fetal rectum, I could clearly make out some sensory terminations in the mucous membrane of the caudal part of the rectum. In the following, I will discuss my findings in comparison with the similar observations obtained by SHIMODA in adult dog.

The sensory fibres coming into the caudal part of the rectum of canine fetus, in company with vegetative fibres, first run via the AUERBACH's plexus into the MEISSNER's plexus, and thence, parting from the vegetative fibres, pass into the subepithelial connective tissue to form their 
terminations therein. Since in fetal dog the formation of the lamina muscularis mucosae is as yet very vague, the boundary between the propria and the submucosa is anything but definite. Therfore, it was impossible to determine in which layer a sensory fibre terminated in most cases, but in any case it was clear that these fibres form their terminations in the subepithelial connective tissue layer.

As the sensory fibres are considerably thicker and darker-staining than the finer vegetative fibres, the histological distinction between these two kinds of nerve fibres is very easy. According to SHIMODA, in the caudal part of the rectum of adult dog the sensory fibres end in part in the lamina muscularis mucosae but more frequently in the propria usually in branched terminations formed around the intestinal crypts.

In my specimens of canine fetus, as stated above, the lamina muscularis mucosae is as yet nearly unformed, so it cannot be laid down with certainly, but it seemed a considerable majority of the fibres ended just at the boundary between the submucosa and the muscularis mucosae and those penetrating into the propria and attaining the vicinity of the intestinal crypts were rather few. Their mode of termination was found much simpler than in adult dog, most of them being of the unbranched type, bifurcated terminations being of very rare occurrence only and branched terminations with more than two branches never being detected. Such observations suggest that the sensory terminations are as yet in the course of development in the latter fetal stage in dogs.

In Fig. 2 is shown a thick sensory fibre fouud in the caudal part of the rectum of a dog fetus, which, running via a MEISSNER's plexus through the submucosa toward the propria, ends sharply without branching at the site where perhaps the lamina muscularis mucosae is to be formed later on. In Fig. 3 we see another thick fibre running amidst fine vegetative fibres, showing some change in size, from a plexus submucous through the submucosa into the propria and similarly ending sharply in an unbranched termination there, but in this case upon reaching the basis of an intestinal crypt.

The mucous membrane lining the very narrow zona columnaris and the zona intermedia of the anus of fetal dog being unprovided with muscularis mucosae, the boundary between the submucsa and the propria is not definite. This subepithelial connective tissue layer, however, is a little better developed in the zona columnaris than in the zona intermedia. In the former, a weak formation papillae into the epithelium is observable, but in the latter no papilla is formed. Such a histological difference between these two zones entails a difference in the level of development of the MEISSNER's plexus and the sensory fibres iu them. So, the MEISSNER's plexus is found far better developed and the sensory fibres more 


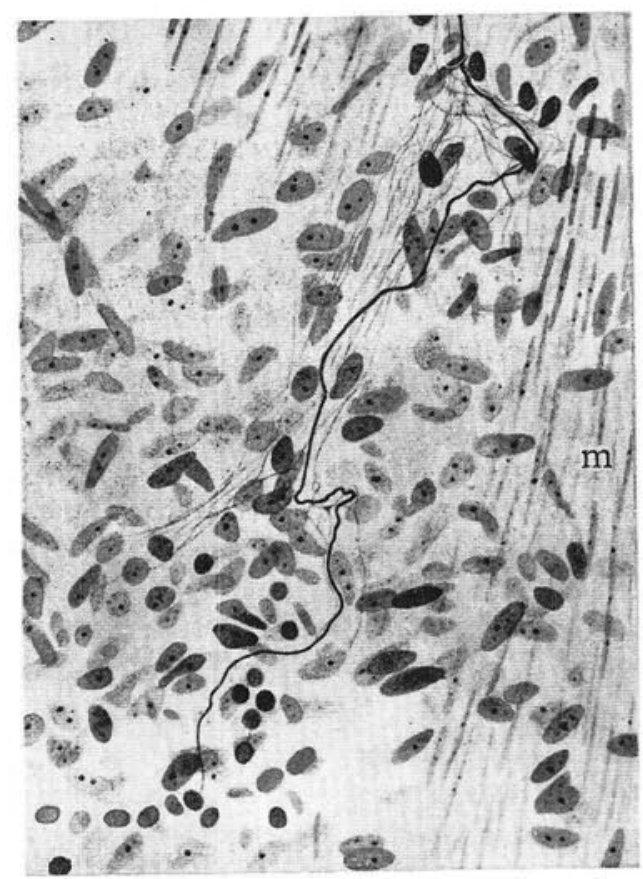

Fig. 2. An unbranched sensory termination found in the subepithelial connective tissue layer of the caudal part of rectum in a canine embryo. Fine nerve fibres are vegetative fibres, $m$ smooth muscle tissue of the inner circular layer of muscularis. Details in the text. Same staining. $\times 500$, reduced to $3 / 4$.

abundant in the columnar than in the intermediate zone. The number of the sensory fibres in the latter, however, is much larger than in the caudal part of the rectum.

The sensory fibres in the anal columnar and intermediate zones of fetal dog run in company with vegetative fibres into the subepithelial connective tissue and usually parting from the vegetative fibres here, end in unbranched terminations, or sometimes very simple branched terminations, of which the bifurcated type is the most frequent. Their terminal fibres generally show little change in size during their courses and usually end in sharp points. Such complex branched terminations as found in adult dog are not yet developed in the fetal anus.

Fig. 4 shows some unbranched terminations formed in the subepithelial connective tissue of a sinus in the columnar zone. Here, the terminal fibres end in sharp points close beneath the epithelium, but never penetrate into the epithelium. An unbranched termination encircling a proctal gland duct along its epithelium is also illustrated herein. Fig. 5 illustrates 


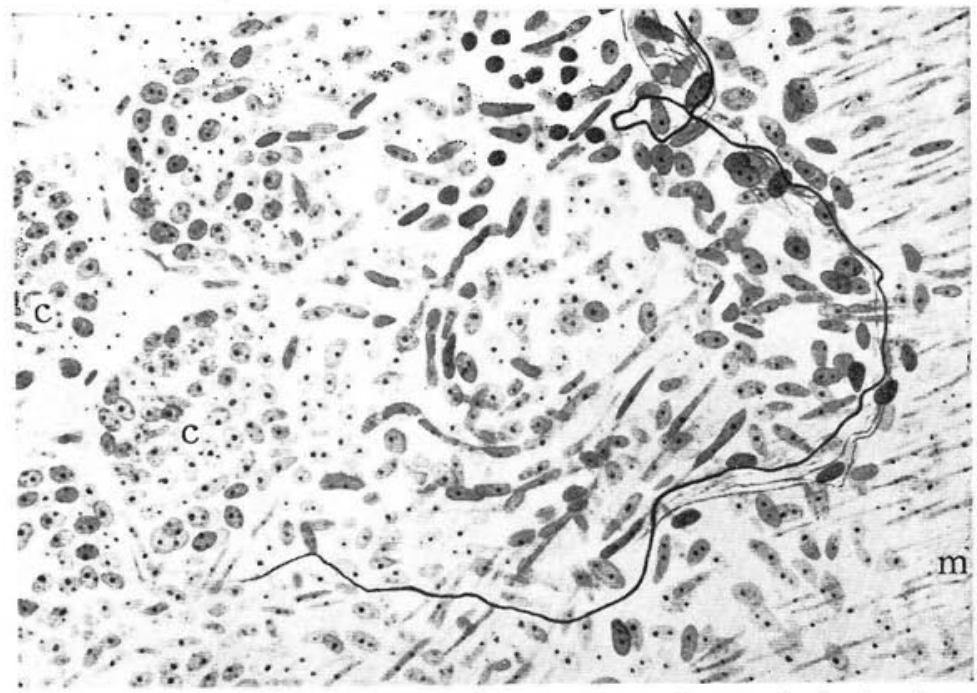

Fig. 3. An unbranched sensory termination formed near the basis of an intestinal crypt $(c)$ in the caudal part of rectum of a canine embryo. Fine fibres are vegetative fibres, $m$ muscularis. Details in the text. Same staining. $\times 400$, reduced to $3 / 4$.

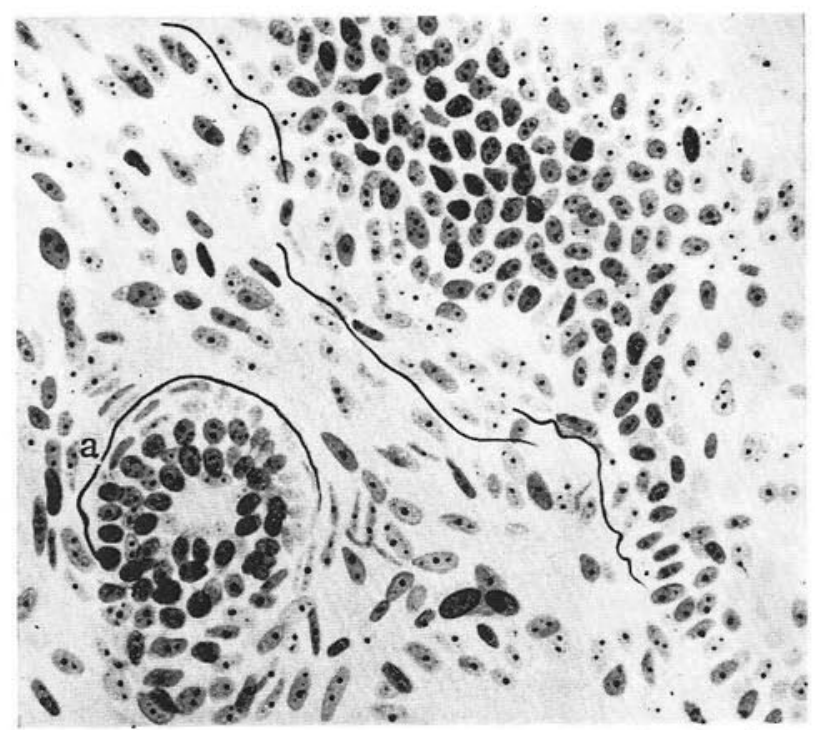

Fig. 4. Some unbranched sensory terminations found subepithelially in a sinus of zona columnaris ani of a canine embryo. $a$ an unbranched sensory termination formed around a proctal gland duct. Same staining. $\times 500$, reduced to $3 / 4$. 


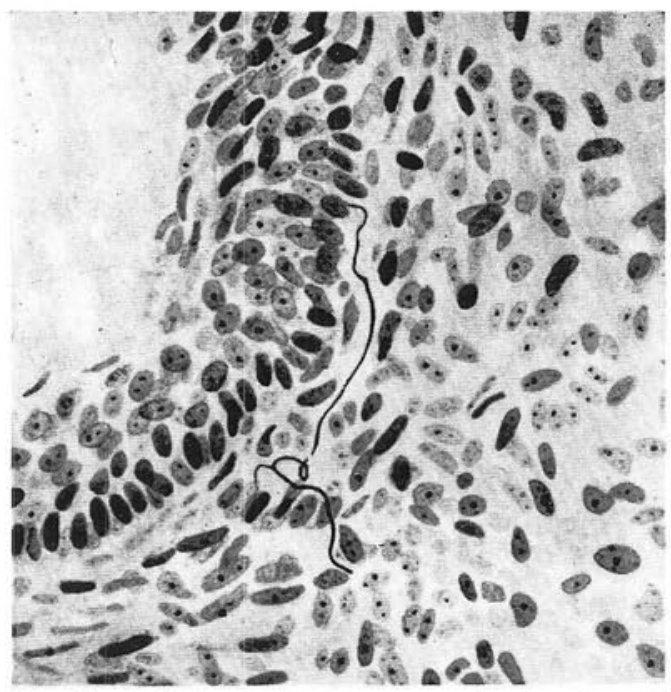

Fig. 5. A bifurcated sensory termination formed directly beneath the stratified flat epithelium of a columna of zona columnaris ani of a canine embryo.

Same staining. $\times 320$, reduced to $4 / 5$.

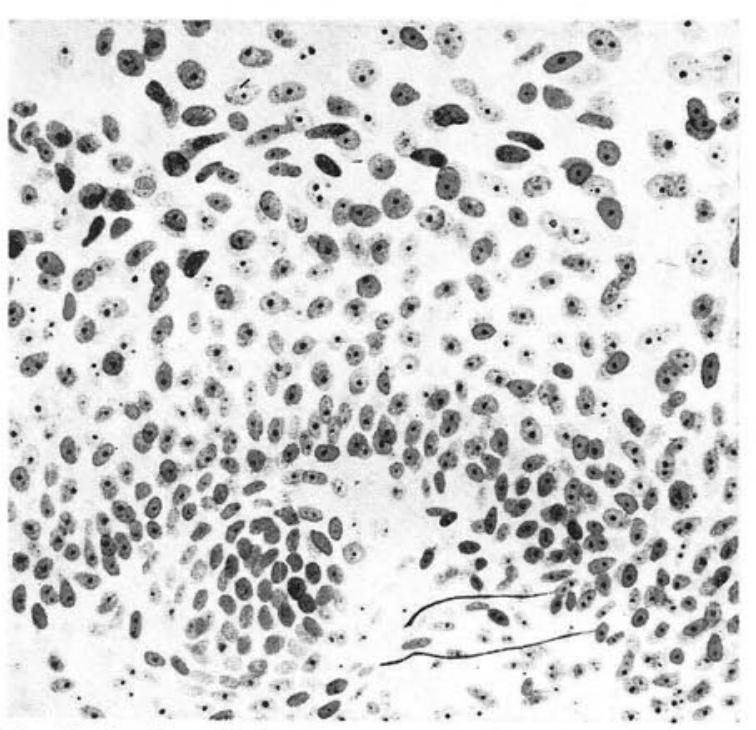

Fig. 6. 2 unbranched sensory terminations formed beneath the bladder-like thick stratified epithelium of zona intermedia ani of a canine embryo. Details in the text. Same staining. $\times 400$, reduced to $3 / 4$. 
a bifurcated sensory termination formed just beneath the stratified flat epithelium of a columna in the zona columnaris, of which also the terminal fibres end before penetrating into the epithelium.

In Fig. 6 we see two unbranched terminations found close beneath the thick bladder-like epithelium lining the zona intermedia, both showing some change in size in the terminal area. Fig. 7 shows a rather typical bifurcated termination found in the propria of the intermediate zone, of which the terminal fibres end sharply.

The above described sensory terminations are also formed around the anal canals and the proctal glands, as have been found in man and some other mammals. These also, in fetal dog, end subepithelially in undranched and

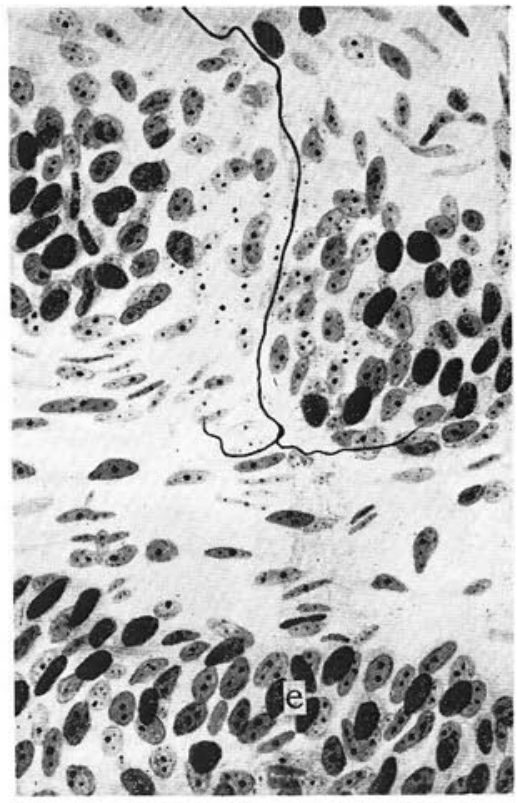

Fig. 7. A bifurcated sensory termination formed in the propria of zona intermedia. Terminal fibres end sharply, $e$ basal part of epithelium. Same staining. $\times 600$, reduced to $2 / 3$.

simple branched, especially, bifurcated forms. For example, in Fig. 4, an unbranched termination is formed around a proctal gland duct in a posture encircling it. The fibre here, showing a little change in size in its course, finally ends in sharp points. In Fig. 8 are shown two unbranched terminations of fibres running around an anal canal (seen on the left side of the picture) while showing some winding courses and chiefly ending sharply. Around the proctal gland duct seen on the right-hand side, several sensory fibres are seen encircling it, most of which end in unbranched terminations, but a few end in bifurcated endings. The terminal fibres of these also end sharply.

SETO has discovered intraepithelial fibres in the epithelium of the anal mucous membrane and of the anal canals and the proctal gland ducts in human fetus as well as in human adults. The existence of similar intraeipithelial fibres was since then demonstred in some adult mammals by some members of this laboratory. Some intraepithelial fibres were found in my specimens of fetal dog too, but in development, they were much poorer than those in human fetus. In the zonae columnaris and intermedia, 


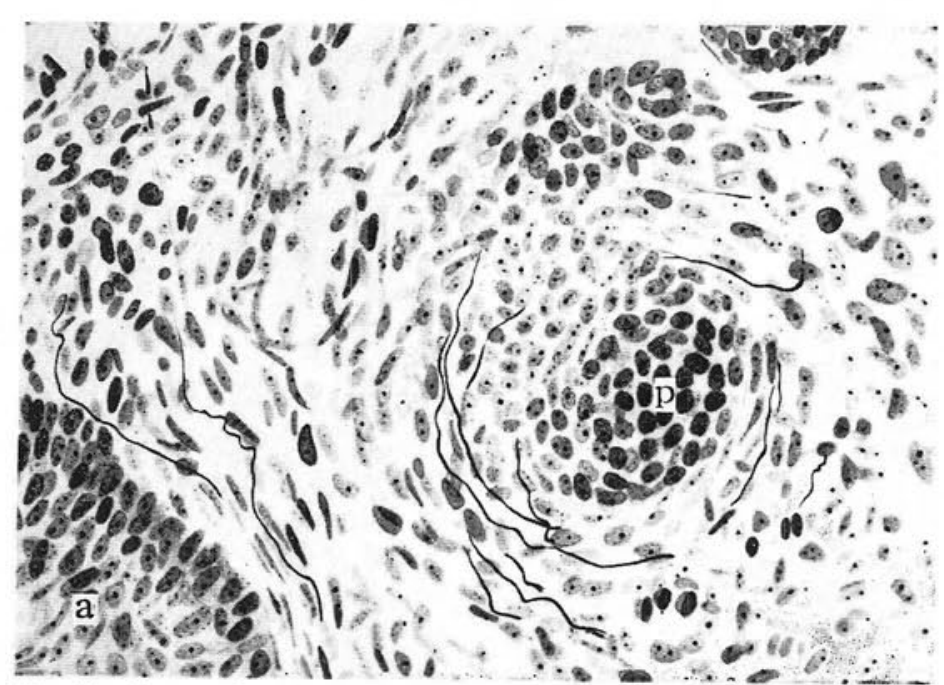

Fig. 8. Some unbranched and bifurcated sensory terminations formed around an anal canal $(a)$ and a proctal gland duct $(p)$ in the anal mucous membrane of a canine embryo. Details in the text. Same staining. $\times 400$, reduced to $2 / 3$.

in the anal canals and the proctal gland ducts of dog fetus intraepithelial fibres ending in the epithelium were not at all rare, but in number and development they were far lower than those in man. Of course, since such intraepithelial fibres are much better developed in adult man than in adult dog, it was not at all difficult to surmise that they would be found far worse developed in dog in fetal stage.

In Fig. 9 are seen a few sensory fibres running along the basis of the epithelium of the zona intermedia and then running up into the based layer of the epithelium but soon ending sharply in it. In Fig. 10 also, many sensory fibres are found running into the propria of the zona columnaris, which end in unbranched or simple branched terminations just subepithelially, except a few that run into the stratified flat epithelium for a short distance and end in its basal layer. The terminal fibres mostly end in sharp points.

In the propria of the zona intermedia ani of human adults a rather large number of genital nerve bodies have been discovered too, but in adult dog, no such corpuscles have ever been found. Since such terminal bodies are found neither in the anus of human fetus, they are probably elaborated postnatally. So it is quite natural that such end bodies have never been found in the zona intermedia of my canine embryo, too. SHIMODA has reported that simple branched terminations are frequently found also in the muscularis of this part of adult dog, but in my fetal sections, I found none of them, perhaps due to their later formation. 


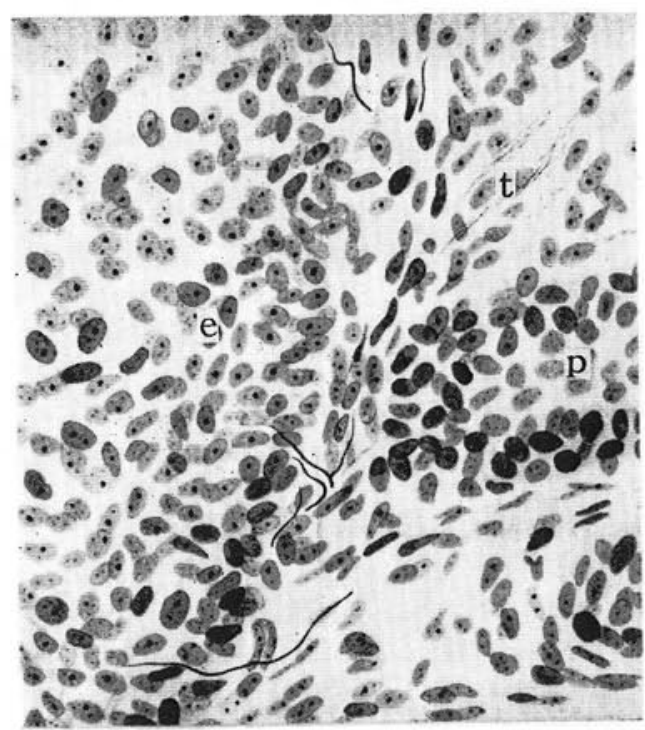

Fig. 9. A few short intraepithelial fibres ending sharply in the basal layer of the epithelium (e) of zona intermedia in a canine embryo. $t$ terminal reticulum, $p$ proctal gland duct. Details in the text. Same staining. $\times 320$, reduced to $3 / 4$.

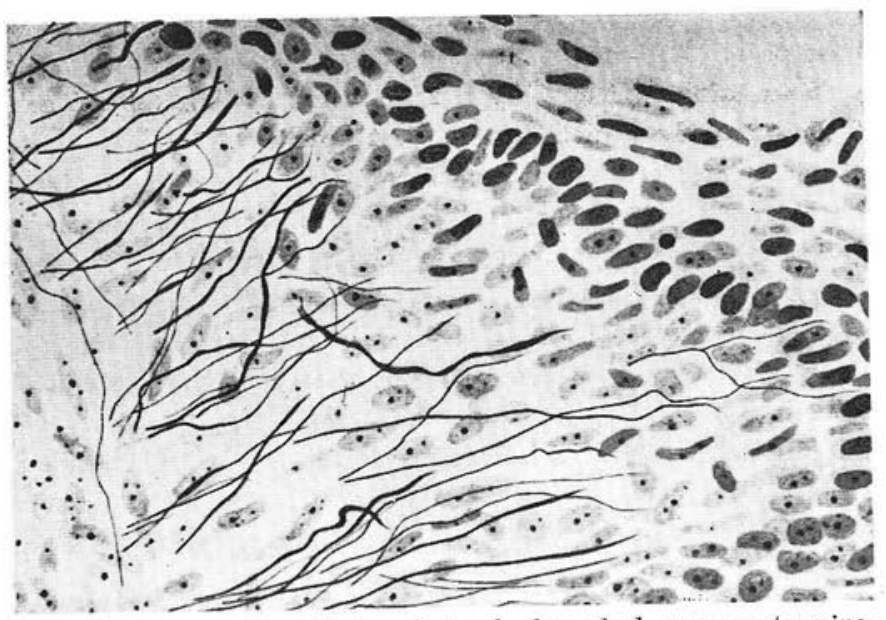

Fig. 10. Many unbranched and simple branched sensory terminations found in the propria of zona columnaris of a canine embryo, of which a few fibres run into the basal layer of the epithelium, to become intraepithelial fibres. Details in the text. Same staining. $\times 400$, reduced to $4 / 5$. 


\section{Summary.}

In a canine fetus of the later fetal stage, the anal mucous part, containing the zonae intermedia and columnaris, is much smaller in area than that in human fetus. The intermediate zone is lined with a bladder-like tsratified epithelium poorer in development than in human fetus. No papillae are formed out of the propria into this epithelium, as little in fetal as in adult dogs. The propria in this as well as in the columnar zone is composed of a connective tissue containing abundant spindle-formed connective tissue cells, and no longitudinal muscle fibres extending down from the muscularis mucosae of the rectum is yet formed between the propria and the submucosa of a similar tissue, as was in the case of the human anus.

In the zona columnaris, the columnae are lined with a 3-4-rowed cylindrical or a flat epithelium, and the sinus with a tall cylindrical epithelium. Unlike that in human fetus, papillae are found in formation out of the propria into these epithelia, even rather markedly in the part nearer the rectum. Anal canals are formed beginning in the epithelium of the zona columnaris and running down along the subepithelial layer before ending in blind sacs, but in number, these are much smaller than in human fetus. The epithelium here is of stratified cylindrical type.

The proctal glands are already in formation. These are found, beside within the mucosa and the tunica muscularis of the anus, also not rarely extending into the rectal mucous membrane. But in fetal dog, they are as yet not nearly full-grown, their end parts being mere epithelial cords and the ducts being indicated by a 2-3-rowed cylindrical epithelium, no sign of their specific structure being yet apparent.

The muscularis of the rectum is composed of an inner circular and an outer longitudinal layers extending down as far as the intermediate zone of the anus, the former layer thence passing over into the $\mathrm{m}$. sphinter ani internus. On the other hand, the outer longitudinal layer partly reaches down along the outside of the $\mathrm{m}$. sphincter ani externus, and gaining in strength, finally arrives at the inside of the coxal bone to end there. I wish to call this the $\mathrm{m}$. dilatator ani.

The ganglia in the AULRBACH's plexus are formed, beside between the two muscle layers above, often enough inside the muscle layers as well and in a small number in the $\mathrm{m}$. dilatator ani too. Smaller ganglia are formed also in the MEISSNER's plexus. Such ganglia are found in the anus as well, but in development these are much poorer than those in the rectum. The ganglion cells are still very ill developed and their multipolarity is as yet sufficiently manifest, so that they are seen as more apolar round cells.

The nerve fibres coming into the distal part of the rectum run via 
the AUERBACH's plexus into the MEISSNER's plexus and come into closest relation with these plexuses. Beside the very fine vegetative fibres, a small number of thick sensory fibres are also found among them. The terminations of the vegetative fibres are already well developed into fullgrown STÖHR's terminal reticula.

The sensory fibres, in company with the vegetative fibres, run also via the AUERBACH's plexus into the MFISSNER's plexus, and thence, parting from the vegetative fibres in most cases, into the subepithelial connective tissue layer to form their terminations there. Since in the dog fetus, the formation of the muscularis mucosae in the rectum is as yet not clearly defined, it is often undefinable in which layer a sensory fibre ends, but it seems that most of them end at the plane where the boundary between the submucosa and the muscularis mucosae is to be formed, except a comparatively few that penetrate further into the propria and attain the vicinity of the intestinal crypts. Their terminal mode is much simpler than those in adult dogs, unbranched terminations occupying the largest majority, and only a few bifurcated terminations representing the branched terminations found here. Their terminal fibres often show some change in size in their courses before tapering off into sharp points, which sometimes run up to the basis of the intestinal crypts, but never into their epithelium.

The subepithelial connective tissue of the mucous membrane of the anus of fetal $\operatorname{dog}$ is better developed in the columnar than in the intermediate zone. In the former zone, papillae are formed, but not in the latter. This histological difference is a measure of the differnt level of development of the MEISSNER's plexus and the sensory fibres in these parts, that is, their dvelopment is better in the columnar than in the intermediate zone. The number of sensory fibres, however, is far larger even in the zona intermedia than in the caudal part of the rectum.

The sensory fibres found in the columnar and the intermediate zones of the anus, upon coming into the subepithelial layer, end in unbranched or very simple branched (bifurcated in the main) terminations. Their terminal fibres usually show little change in size but gradually taper off into sharp points and end just beneath the epithelium. Similar terminations are found also around the anal canals and the proctal gland ducts.

In dog fetus as well as in human fetus (SETO), intraepithelial fibres were discovered in the epithelia of the anal mucous membrane, the anal canals and the proctal gland ducts, but both in number and development, they are far lower in the former than in the latter. As these, however, are much poorer in adult dogs than in human adults (SHIMODA), it is of course natural that in fetal dogs they should be doubly poorer. These intraepithelial fibres in the anus of fetal dog, upon penetrating into the 
spithelium, run a short course and end usually in unbranched terminations with sharp points.

No such a thing as a genital nerve body could be found in the propria of the zona intermedia ani of dog fetus. Neither could I find sensory terminations in the tunica muscularis.

\section{内 容 自 抄。}

胎生後期の犬胎児の直腸下部に於ける Auerbach 神経叢の神経節は内外 雨筋層間の外，稀ならず筋層内飞る又著者の肞門散大筋の中にも発見され る。 Meissner 神経誏内にはより小型の神経節を見る。以上の神経節は肛門 粘膜部にも見られるが，直腸に於けるよりは発達劣勢である，神経細胞は 甚だ幼弱性を示す.

直腸下部に対寸る外来神経は多数の植物線維と少量の知覚線維とから成 る，前者は広く抬散の後既に完成された Stöhr 民終網に移行して終る．知 覚線維は昌ら腸隠响から多少離れた上皮下組織内に終る。その終末様式は 甚だ単純で，多くは非分岐性，然し稀には2丒分岐性終末で表わされ，終 末枝の先端は腸鿵简に達することもあるが，上皮内には進むことなく，専 ら尖鋭状に終る。

肛門粘膜部の中間帶と柱带とでは雨带の組織構成の差買に一致して神経 分布発達の上飞多少の優劣を見る。即ち Meissner 神経叢と知覚線維も柱 带では中間带に於けるよりはより良好な発達を示す。但し中間带に於ける 知覚線維でる直腸下部の夫に比すれば遙かに優勢である。

柱带と中間带に来る知覚線維は上皮下に進み，非分岐性及び 2 文分岐性

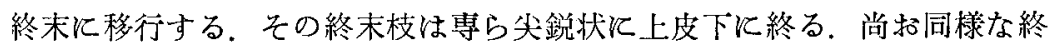
末は少量に存する肚門管及び良く発達する肚門腺管の周囲にも形成される。 以上知覚終末の終末枝は直腸下部に於けると異なり，屡々更に各上皮内に 進んで上皮内線維に移行する，但しての発達状態は人胎児の場合（瀬戸） て比すれば遥かに劣勢であり，且つその多くは非分岐型で表わされる。

\section{References.}

Izumi : Arch. hist. jap. 9 (1955). - Niizuma : Arch. hist. jap. 9 (1955). - Niizuma, Nozaki, Komatsu a. Numata : Arch. hist. jap. 9 (1955). 一 Ottaviani : Z. mikr.-anat. Forsch. 47 (1940). - Seto: Arb. Anat. Inst. Sendai. 23 (1940). - Advance of Medicine. Vol. 5. Tokyo, Nanjo Shoten, 1948. - Okajimas folia anat. jap. 28 (1956). - Shimoda : Arch. hist. jap. 7 (1954). - Sotelo : Z. Zellforsch. 41 (1954). - Utsushi : Tohoku J. exp. Med. 60 (1954). — Yamada : Tohoku J. exp. Med. 54 (1951). - Yokoyama : Arch. hist. jap. 12 (1957). 